\title{
Narrativas visuais sobre a Primeira Guerra na revista A Cigarra ${ }^{1}$
}

\author{
Ana Regina RÊGO² \\ Antonio Carlos HOLFELDT ${ }^{3}$ \\ Ranielle Leal MOURA ${ }^{4}$
}

\begin{abstract}
Resumo:
O conflito que se estabeleceu no continente europeu entre os anos de 1914 e 1918 terminou por envolver nações de outras partes do planeta, dentre elas, o Brasil, que formalmente entrou em guerra com a Alemanha em dezembro de 1917. Entretanto, ainda em 1914, a imprensa brasileira passou a participar ativamente do conflito. A revista ilustrada A Cigarra, publicada na cidade de São Paulo, e direcionada à elite, esteve atuante durante todo o período da guerra e foi uma das que mais investiu em narrativas visuais sobre o tema. Este estudo se concentra nas narrativas imagéticas do periódico mencionado e tem como objetivo trabalhar a lacuna do discurso historiográfico, que dedica pouco ou nenhum espaço ao Brasil no conflito em pauta. A intenção é investigar a historicidade e a força das imagens na construção dos contextos que chegavam aos brasileiros. A metodologia tem caráter qualitativo e guia-se pela Hermenêutica da consciência histórica (RICOEUR, 2010).
\end{abstract}

Palavras-chave: Primeira Guerra Mundial. Brasil. A Cigarra. Narrativas visuais.

\section{Visual narratives about the First War in the magazine $A$ Cigarra}

\begin{abstract}
:
The conflict, which settled on the European continent between the years 1914 and 1918, ended up involving nations from other parts of the planet included among them Brazil, that formally entered war with Germany in December 1917. Meanwhile, in 1914, the Brazilian press begun participating actively in the conflict. The illustrated magazine A Cigarra published in the city of São Paulo, and aimed at the São Paulo elite, was active during the whole period of the war and was one of the most engaged on iconographic narratives about the subject. This study focuses on the imagery narratives of the aforementioned periodical and aims to work on the gap in the historiographic discourse, which dedicates little or no space to Brazil in the conflict at hand. The intention is to investigate the historicity and strength of the narratives mentioned in the construction of the contexts that reached Brazilians. The methodology is qualitative and guided by the Hermeneutics of historical consciousness (RICOEUR, 2010).
\end{abstract}

Keywords: World War I. Brazil. The Cicada. Iconographic Narrative.

\footnotetext{
${ }^{1}$ Uma versão diferente e maior deste artigo foi apresentada em mesa temática no IAMHIST Conference Paris 2017, realizado pela The International Association for Media and History, na Universidade de Paris 2 em julho de 2017. O evento não publicou anais. Programacão disponível em: http://iamhist.net/?s=IAMHIST2017

${ }^{2}$ Doutora em Processos Comunicacionais, Pós-Doutora em Comunicação e Cultura, professora do PPGCOMUFPI. E-mail: anareginarego@gmail.com

${ }^{3}$ Doutor em Linguística e Letras, Pós-Doutor em Comunicação, professor da FAMECOS-PUC-RS. E-mail: a hohlfeldt@yahoo.com.br

${ }^{4}$ Doutora em Comunicação, Instituto de Comunicação e Cultura-ICC. E-mail: ranileal29@gmail.com
} 


\section{Narrativas visuales sobre la Primera Guerra en la revista $A$ Cigarra}

Resumen:

El conflicto que tuvo lugar en el continente europeo entre 1914 y 1918 terminó involucrando a naciones de otras partes del planeta, incluso Brasil, que entró formalmente en guerra con Alemania en diciembre de 1917. Sin embargo, en 1914, la prensa brasileña comenzó a participar activamente en el conflicto. La revista ilustrada $A$ Cigarra, editada en la ciudad de São Paulo y dirigida a la élite, estuvo activa durante toda la guerra y fue una de las que más invirtió en narrativas visuales sobre el tema. Esta investigación se centra en las narrativas visuales de la revista mencionada y tiene como objetivo trabajar sobre la brecha en el discurso historiográfico que dedica poco o ningún espacio a Brasil en el conflicto que nos ocupa. La intención es investigar la historicidad y fuerza de las imágenes en la construcción de contextos que llegaron a los brasileños. La metodología tiene un carácter cualitativo y está guiada por la hermenéutica de la conciencia histórica (RICOEUR, 2010).

Palabras clave: Primera Guerra Mundial. Brasil. La cigarra. Narrativas visuales.

\section{Introdução}

A guerra que eclodiu no início do século XX e que envolveu as nações europeias foi deflagrada pontualmente após o assassinato do Arquiduque Franz Ferdinand da Áustria em Sarajevo-Bósnia ${ }^{5}$ e se constituiu como um reflexo de décadas de disputas geopolíticas e econômicas das potências do norte, que dividiam, entre si, as nações e os povos do hemisfério sul (HASTINGS, 2014).

No século anterior, os países com interesses comuns se alinhavam em torno de blocos, procurando impor posições econômicas ao continente europeu. Tudo era inicialmente negociado e, posteriormente, disputado. Assim, nasceu, de um lado, a Tríplice Aliança, das potências centrais, liderada pela Alemanha e pelo Império Austro-Húngaro, e, de outro, a Tríplice Entente, composta pela Inglaterra, França e Rússia ${ }^{6}$. Com a guerra, outros países foram aderindo a um dos lados e declarando guerra aos aliados da frente contrária. Como exemplo, podemos mencionar Itália, Japão, Estados Unidos e até mesmo o Brasil (RÊGO; LEAL, 2015).

A primeira grande guerra, considerada por Hastins (2014) e Gilbert (2017) como um momento em que as armas de grande alcance e destruição ganharam destaque, causando um impacto considerável e provocando um enorme número de mortos em pouco tempo, foi também a primeira a ser completamente coberta pelo moderno jornalismo que se consolidava como campo discursivo e simbólico que tinha/tem e vendia/vende como principal valor a

\footnotetext{
${ }^{5}$ Este evento funcionou como um estopim para o início do conflito bélico (HASTINGS, 2014).

${ }^{6}$ A Rússia abandonou a guerra após a deflagração da Revolução interna em 1917 (GILBERT, 2017).
} 
ideia coletiva de uma verdade ${ }^{7}$ dos fatos. Ambos os lados possuíam jornalistas atuando no front, que procuravam informar seus países e seus povos sobre o que acontecia nas batalhas.

Em complemento, as agências de notícia trabalhavam a pleno vapor, fazendo circular informações várias vezes ao dia; contudo, informações nem sempre verídicas e muitas com grande carga de ficção ${ }^{8}$, já que, por essa época, os processos manipulatórios chegaram ao jornalismo com grande força durante o conflito e eram vistos como necessários, pois os governos trabalhavam intensamente o apoio populacional e, para tanto, era preciso convencer os conterrâneos dos perigos que os inimigos representavam para cada sociedade e seu modo de viver.

No que concerne às narrativas imagéticas, conseguimos identificar três tipos frequentes nos jornais e nas revistas: 1. As fotografias que traziam ou imagens do front ou imagens dos oficiais mais renomados e dos "candidatos" a heróis; 2. As gravuras ou litogravuras que traziam cenas da guerra; 3 . As charges que tratavam de levar um pouco de humor e criticidade tanto às ocorrências da guerra quanto às posições dos países em relação ao conflito.

Assim, considerando o elevado número de imagens sobre o conflito nos primeiros anos, é que neste artigo analisaremos tão somente as imagens fotográficas e as gravuras ou litogravuras localizadas na revista A Cigarra nos meses de agosto, setembro, outubro e novembro do ano de 1914, a saber: três imagens de cada edição mencionada, totalizando 12 imagens.

O nosso texto inicia com uma breve explanação sobre o jornalismo durante o conflito, tendo como pano de fundo o Brasil. Posteriormente, abordamos as narrativas imagéticas e as possibilidades interpretativas que se colocam a partir delas, e, por último, realizamos a interpretação das imagens escolhidas como observáveis com base na Hermenêutica da consciência histórica e da tríplice mímesis ricoueriana.

\footnotetext{
${ }^{7}$ Sabe-se que o jornalismo trabalha com construções do real, apresentando recortes a partir de pontos de vista, portanto, atuando subjetivamente em vários momentos do processo de construção da notícia, embora mantenha o discurso de objetividade e imparcialidade, necessários à credibilidade e reputação do campo.

${ }^{8}$ Com o intuito de sensibilizar e conseguir a adesão e o apoio da sociedade para a guerra, os Estados usavam os meios de comunicação, sobretudo, os jornais, trabalhando pautas que sensibilizavam a população contra os opositores. Desse modo, construíam-se notícias fictícias com o fim de conseguir que um grande número de pessoas pudesse apoiar seus países na caríssima empreitada da guerra. Exemplos podem ser vistos em Rêgo e Leal (2015), Hastings (2014), Claro (2011) e Giorgis (2014).
} 


\title{
O jornalismo em tempos de guerra
}

Rêgo e Leal (2015) investigaram a atuação da imprensa brasileira durante o conflito de 1914-1918 procurando demonstrar que os processos manipulatórios dos governos europeus envolvidos em cada lado do conflito visibilizados em seus meios de comunicação também se refletiam na imprensa brasileira, cujos jornais eram alimentados pelas agências de notícias aos quais estavam filiados, reproduzindo fielmente os discursos apresentados no continente europeu, obviamente, conforme seus interesses. Assim, é comum localizarmos nos jornais do Sudeste uma visão do conflito mais favorável aos países componentes da Tríplice Entente, enquanto no Sul, muitos jornais se colocavam ao lado dos alemães e seus aliados.

As pesquisadoras mencionadas concordam, portanto, com as observações realizadas por Hastings (2014) e Albert e Terrou (1990), no ambiente europeu, e por Claro (2011) e Giorgis (2014), no ambiente brasileiro, e destacam que

\begin{abstract}
A propaganda que inicialmente se mostrou improvisada foi aos poucos sendo planejada e terminou se tornando orquestrada sob o julgo dos governos que interviram diretamente na construção das notícias, determinando o que deveria ou não ser visibilizado. Esse modus operandi propagandístico foi ao final eficaz, mas provocou um descompasso entre a opinião da sociedade e a dos combatentes, que como dito não "reconheciam a guerra que faziam". Para os autores, "[...] a imprensa dilapidou nessa ocasião um enorme capital de confiança e teve muita dificuldade pra reconstituí-lo com a chegada da paz" (RÊGO; LEAL, 2015, p. 322)
\end{abstract}

Já Sidney Garambone (2003) procura mostrar que houve um relativo equilíbrio nesta cobertura: algumas publicações foram mais simpáticas aos alemães, enquanto outras penderam para os franceses e ingleses, mas, de modo geral, segundo o autor, houve um claro equilíbrio, com objetividade a respeito das informações trazidas ao leitor brasileiro, até o momento, evidentemente, em que o Brasil declarou guerra aos alemães e a censura foi estabelecida sobre os meios de comunicação. Para Garambone (2003, p. 32), estudar este evento a partir dos jornais, tem especial importância porque lança "um feixe esclarecedor sobre um período diplomático ainda às escuras".

Vale ponderar, nesse contexto, que embora possa ou não ter havido um equilíbrio na construção de narrativas a favor de cada lado do conflito, o jornalismo brasileiro e sua atuação no período da guerra aqui analisada teve atuação concordante com os países europeus e não diferiu das práticas adotadas nos países centrais no conflito. Por outro lado, é válido ainda enfatizar que, desde 1914, nossa imprensa já estava diretamente envolvida no conflito, 
enquanto que o governo e suas forças armadas efetivamente entram na guerra no final de 1917. Contrariamente à batalha travada nos jornais e demais periódicos, as forças armadas terão uma atuação mínima.

É, portanto, nesse contexto que as imagens da guerra são aqui interpretadas. Não apenas em suas proposições imagéticas, mas, principalmente, como narrativas que só fazem sentido em seu contexto e temporalidade e que guardam, em si, historicidade e experiência.

\section{O potencial narrativo da imagem e a Hermenêutica- o método da interpretação}

Dentre as várias formas de se explorar a imagem como fonte primária para a construção do discurso histórico no campo da Comunicação, vale mencionar as possibilidades que apontam para as construções imagéticas como dotadas de grande potencial testemunhal, uma vez que, situadas em seus contextos e temporalidades, carregam narrativas capazes de revelar detalhes da historicidade ${ }^{9}$ dos fenômenos que revelam, sobretudo, porque carregam em si, a potência do paradoxo entre a credulidade e a dúvida (RICOEUR, 2012). Por outro lado, não se pode desconsiderar a perspectiva que analisa a imagem como uma narrativa sobre o passado, obviamente, uma determinada narrativa, dirigida, direcionada, recortada e construída a partir de olhares determinados.

Hibridizando as proposições das perspectivas mencionadas de forma sintética acima, podemos realizar uma provocação intencional e inicial, afirmando que toda imagem carrega em si um potencial narrativo sobre o fenômeno que revela, contudo, se, como afirma Agamben (2015), toda potência carrega em si uma não potência ${ }^{10}$, todo poder reflete um não poder. As imagens, como manifestações comunicacionais, podem ou não cumprir com a intencionalidade de potência narrativa que carregam. Ou seja, as imagens revelam e visibilizam, tanto quanto escondem ou silenciam.

No desenho textual, as narrativas imagéticas, independentemente de sua configuração e suporte, pressupõem a revelação de algum fato ou fenômeno que parte de intenções ocultas ou não, e que terminam por se revelar diretamente no próprio texto. Por esta perspectiva, as narrativas imagéticas não revelam ou defendem uma verdade absoluta, mas podem facilitar a compreensão do mundo a partir do potencial testemunho de fatos e experiências, que carregam em seu íntimo. São, portanto, imagens de uma experiência e do relacionamento desta, com as possibilidades de verdade.

\footnotetext{
${ }^{9}$ Historicidade concebida aqui na concepção heideggeriana (HEIDGEGGER, 2006).

${ }^{10}$ Agamben (2015) trabalha com a potência do pensamento a partir de Aristóteles.
} 
O círculo hermenêutico ricoeuriano proposto a partir de uma dupla entrada - de um lado pela poética Aristotélica e, de outro, pela concepção temporal de Agostinho e Aristóteles - se compõe de três momentos: pré-figuração, configuração e refiguração, que, em suma, conformam a tríplice mimesis. O círculo possibilita o interpretar da realidade, relacionando narrativa e temporalidade, pois, para Ricoeur (2010), o tempo só ganha corpo por meio da narrativa, que por sua vez, só se estrutura e faz sentido a partir da experiência temporal.

Meneses (2006, p. 1) alerta para o fato de que a imagem ativa, de certo modo, uma análise maniqueísta em que "[...] preservacionismo e mudança são considerados como extremos representativos do bem e do mal, sem atinarmos para a dialética de conservação e transformação que constituem a lei de nossa existência". Para esse autor, são as possibilidades postas pela memória que permitem que a vida humana seja carregada de sentimento e ganhe inteligilibidade.

As imagens traduzem desejos de visualidade, e aqui nos apropriamos do pensamento de Arendt (2016) ${ }^{11}$, quando esta afirma o querer enquanto atividade do espírito. Nos casos interpretados, o desejo dos fotógrafos e artistas em relação ao que buscavam representar. Então, a possibilidade do real que a imagem revela se hibridiza com a vivência do sujeito. A imagem mostra, ao tempo em que esconde. Reverbera o foco e a luz e silencia o que relega à sombra.

Assim, considerando a imagem como uma narrativa, entende-se que esta passou em qualquer nível por uma edição direcionada por um determinado olhar, compondo o texto em que tanto dá visibilidade, quanto se torna visível.

No caso aqui em análise, as imagens encontram-se adormecidas em seu suporte de memória há mais de um século, e ao serem, por nós, chamadas a manter um diálogo com a contemporaneidade a partir das inquietações que nos guiam na presente investigação, retomam as qualidades simbólicas que sempre carregaram enquanto potenciais narrativas de uma contextualidade e de uma dada temporalidade, às quais se acrescentam outras características nascidas do encontro entre o nosso olhar e a configuração de uma ação narrada pelas imagens do passado.

$\mathrm{Na}$ presente investigação não temos a pretensão de considerar as imagens como reproduções do mundo, ou sequer buscamos representações, mas nos situamos como observadores das possibilidades de revelação (político/ideológicas) com que as imagens podem nos contemplar. Buscamos, de certo modo, a historicidade perdida em construções de

\footnotetext{
${ }^{11}$ Hannah Arendt, em A vida do Espírito, situa o querer como a segunda atividade do espírito.
} 
um discurso histórico; buscamos a cultura e o contexto em seu tempo, por meio das narrativas imagéticas localizadas na revista A Cigarra.

Vale destacar que utilizamos a Hermenêutica da consciência histórica de Ricoeur (2010) como guia para nosso processo interpretativo. Isto significa que procuramos interpretar os padrões imagéticos das imagens veiculadas na revista a partir dos conceitos de ser afetado pelo passado, assim como das divisões conceituais que o autor faz da concepção de tradição como autoridade do passado, tradições que têm na linguagem o elemento primordial e tradicionalidades como meio de ligação intergeracional de valores. $\mathrm{O}$ círculo hermenêutico em seus estágios de pré-figuração, configuração e refiguração da narrativa é ativado para facilitar o processo interpretativo. As possibilidades apresentadas pelo círculo ricoeuriano mencionado nos permitem maior flexibilidade compreensiva e interpretativa, ao tempo em que possibilita uma maior visualidade das ações narradas.

\section{As narrativas visuais sobre a Primeira Guerra na revista $A$ Cigarra}

Nos primeiros anos do século XX, as revistas ilustradas e de variedades publicadas no Brasil integraram e testemunharam transformações na sociedade, no espaço público, na cultura, etc. Acompanhavam o crescimento urbano das cidades e procuravam interagir com o progresso, assim, ofereciam uma boa leitura da produção de grandes escritores e poetas, matérias jornalísticas com fotografias (que era novidade e um diferencial), charges, como também anunciavam produtos da indústria e do comércio nacional ou importado.

Nesse contexto, existiu, ao longo do século XX, uma grande diversidade de revistas no cenário nacional, destacando-se, dentre elas: Semana Ilustrada; Revista da Semana; O Malho; Kosmos; Fon-Fon!; Careta; Revista Ilustrada São Paulo; Diretrizes; O Cruzeiro; Manchete; Realidade; e Veja.

Além dos periódicos mencionados, é possível citar outros tantos e, dentre eles, podemos destacar A Cigarra $^{1213}$, objeto deste estudo, que surgiu em 06 de março de 1914, em São Paulo, fundada pela firma Gelásio Pimenta \& Cia, sociedade formada por Gelásio Pimenta e o Coronel Durval Vieira de Souza. Tinha sua redação localizada na Rua Direita, 8A, e a oficina de impressão na Rua da Consolação, 100-A, em São Paulo. Na década de 1940,

\footnotetext{
${ }^{12}$ A revista teve uma grande aprovação do público feminino na época, passando, com o tempo, ao segmento das revistas femininas (BRAGLIA, 2011).

${ }^{13}$ É importante destacar que no século XIX existiu uma revista ilustrada, conhecida também como A Cigarra. Essa revista surgiu em 1895, lançada pelo ilustrador português Julião Machado e pelo redator Olavo Bilac e administrada por Manoel Ribeiro Junior (SILVESTRE, 2008).
} 
passou a integrar o Grupo dos Diários Associados, do jornalista Assis Chateaubriand (SODRÉ, 1999; BRAGLIA, 2011).

A revista em questão refletiu transformações ocorridas no século $\mathrm{XX}$, principalmente sobre o processo de modernização vivida pela cidade de São Paulo. Trazia em suas páginas diversidade de conteúdo, que ia da produção de artigos e crônicas sobre artes plásticas, música e teatro às coberturas políticas, sociais, religiosas e esportivas. E era essa diversidade sem hierarquias que fazia com que A Cigarra atingisse o maior número possível de leitores. No ano de 1917 se tornou a revista de maior circulação do estado de São Paulo, além de atingir um público dos estados do Rio de Janeiro, Minas Gerais, Paraná, Santa Catarina e Rio Grande do Sul, com uma tiragem que chegou, na época, a 25 mil exemplares (BRAGLIA, 2011). Atingia variados tipos de público leitor, por isso, trazia textos com uma linguagem descontraída, enquanto também dava espaço para artigos com uma linguagem um pouco mais formal.

É válido destacar que a revista fez uso das novas técnicas de reprodução de imagens (fotografias e gravuras) disponíveis nos primeiros anos do século XX, com a utilização de retículas de meio-tom que possibilitavam o uso de cores como preto, salmão, azul ou verde, dando um colorido particular às imagens, que se tornavam atrativas ao olhar do leitor, acostumado à perenidade dos longos textos.

A Cigarra também ficou famosa por seus colaboradores. Nela conviviam escritores e intelectuais conhecidos na cena brasileira, como Guilherme de Almeida, Oswald de Andrade, Léo Vaz, Menotti Del Picchia, Paulo Setúbal, Monteiro Lobato, Olavo Bilac, entre outros (BRAGLIA, 2011; MATOS, 2008).

Outro aspecto a ser ressaltado é a constituição do periódico. Os exemplares eram quinzenais e variavam entre 50 e 100 páginas, sendo que, em sua maioria, eram iniciados por páginas contendo anúncios publicitários. Em seguida, havia a seção de "Crônicas", depois meia página dedicada ao expediente e, na sequência, notícias, reportagens e fotografias, alternadas com páginas contendo contos, poesias e seções dedicadas ao entretenimento (MATOS, 2008). O periódico possuía um discurso "triunfalista" que estava “[...] ancorado na ideia de progresso e no processo de modernização pelo qual passava a cidade de São Paulo. O periódico, desse modo, teria definido um perfil editorial de acordo com os valores da elite paulistana à frente dessa modernização" (MATOS, 2008, p. 2).

A Cigarra combinava notícias e reportagens de interesse social e entretenimento de 
forma harmônica. Manteve um perfil editorial eclético, com um padrão gráfico diferenciado, e esteve no mercado da imprensa ilustrada até 1975.

A guerra teve início no final do primeiro semestre de 1914, mas só começou a ganhar corpo nos periódicos brasileiros, sobretudo, a partir de agosto daquele ano, motivo pelo qual optamos por interpretar os exemplares concernentes ao segundo semestre daquele ano.

\section{Imagens da guerra em $A$ Cigarra}

Nosso percurso analítico tem início na edição de agosto de 1914, em que o conflito já se encontra instalado na imprensa brasileira com grande intensidade e refletindo o debate público que acontecia em todo o país, mas com maior ênfase em São Paulo, Rio de Janeiro e no sul do Brasil.

A edição de agosto de 1914 é particularmente especial porque já oferece muito espaço para discussão do conflito e de temas correlatos. A coluna Bric a Brac, por exemplo, traz notas satíricas sobre o Kaiser alemão, o imperador da Aústria e o czar da Rússia.

Contudo, já na capa é possível identificar a contextualidade da guerra na linha narrativa da revista. Na imagem da capa, a pergunta “Qual será sua bandeira?” procura situar os leitores no conflito e, ao mesmo tempo, guiar seus posicionamentos por meio das narrativas textuais e imagéticas que se seguem. O momento de introdução do leitor nas narrativas do conflito bélico acontece logo no primeiro contato com a revista. A construção da narrativa se inicia na primeira imagem em que a configuração se apresenta enquanto síntese da imaginação criativa que consolida discordâncias em uma imagem concordante que oferece à guerra e ao mesmo tempo, uma dúvida de natureza, essencialmente, feminina. 
Imagem 1- A Cigarra, agosto de 1914

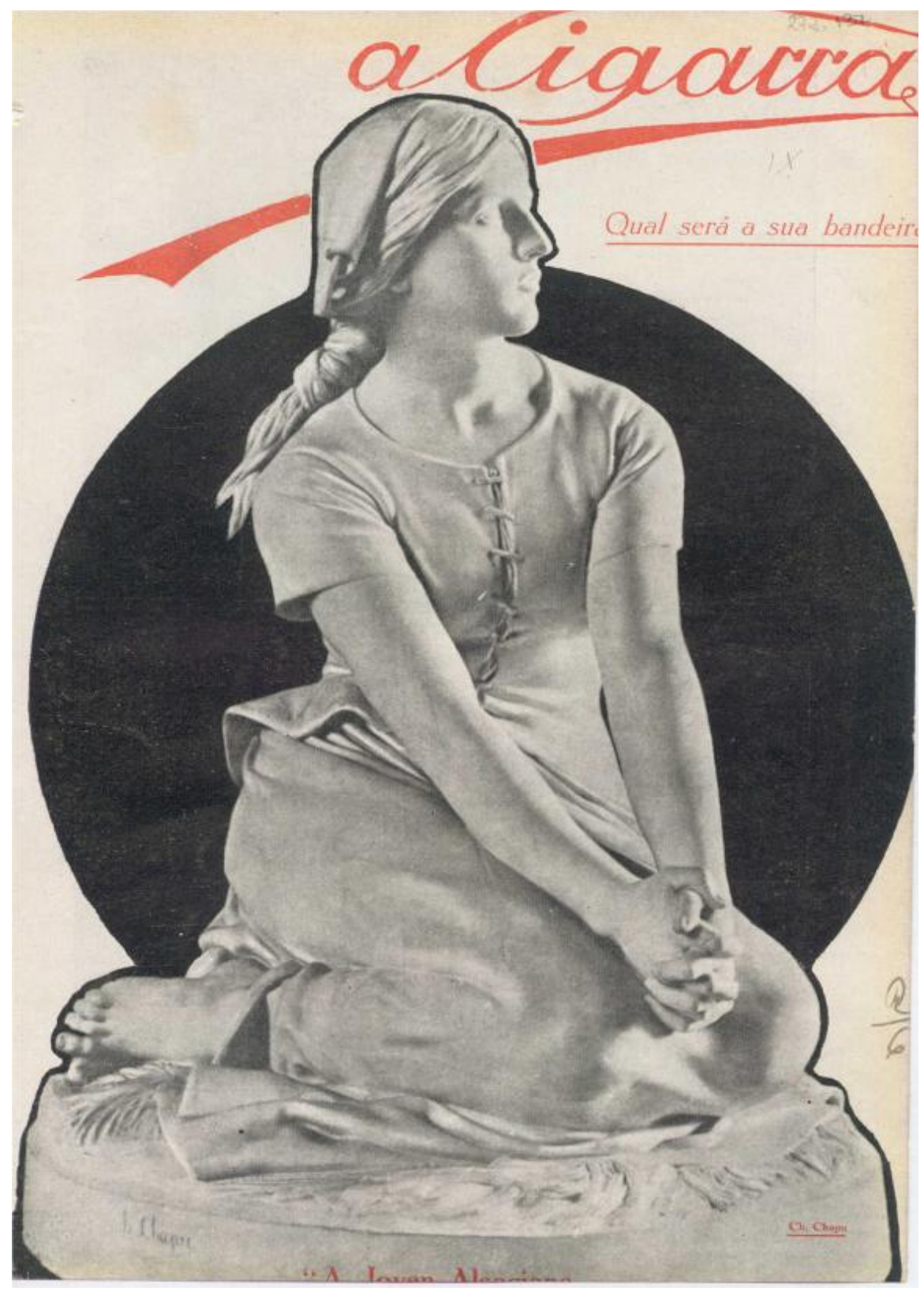

Fonte: Memória da Imprensa- Arquivo do Estado de São Paulo.

Em virtude da deflagração do conflito na Europa, os oficiais franceses que estavam no Brasil a convite do governo brasileiro para treinar nossos militares na chamada Missão francesa foram chamados para o front de batalha. Na edição da revista, a cobertura do evento de partida desses oficiais é realizada em cinco páginas com várias fotos que, em sua maioria, ocupam meia página cada. A fotorreportagem (ainda bem diferente do formato das décadas posteriores), intitulada "A Guerra Europeia", mostra o empenho do periódico em dar visibilidade à partida dos oficiais franceses da Estação da Luz, em São Paulo, em direção ao porto de Santos, onde pegariam o navio para a França, como podemos conferir na Imagem 2. 
Imagem 2 - A Cigarra, agosto de 2014

A Guerra Européa

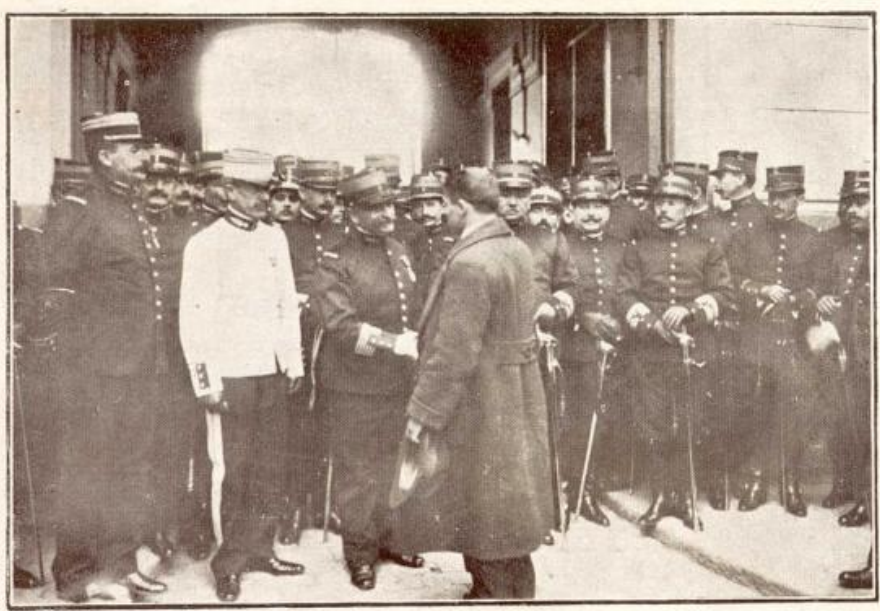

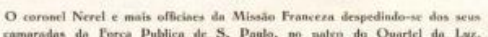

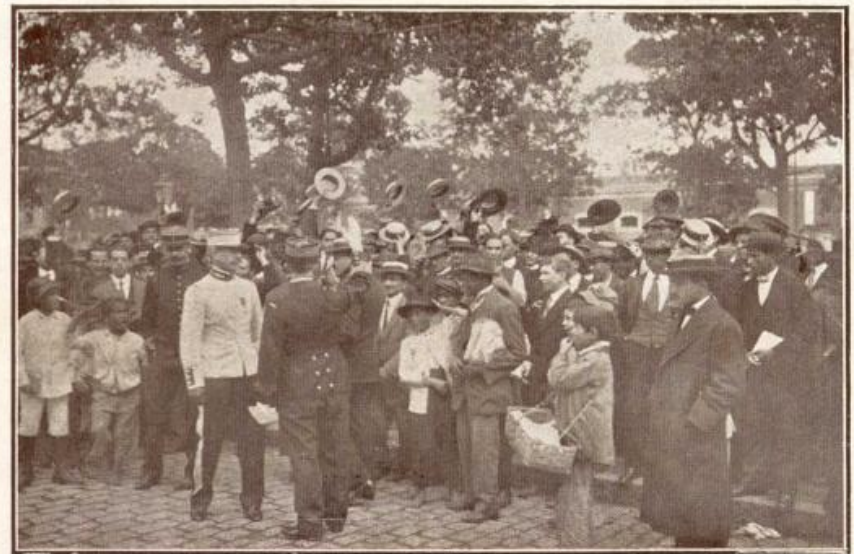

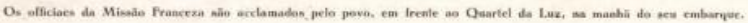

Fonte: Memória da Imprensa- Arquivo do Estado de São Paulo.

É válido, no entanto, ressaltar que a revista também se dedicou a cobrir a partida dos oficiais e reservistas alemães e austríacos que estavam se despedindo de suas famílias e viajando para as trincheiras do conflito, como podemos visualizar na próxima fotografia (Imagem 3). Essa cobertura revela a intencionalidade do periódico de ainda manter uma imagem de imparcialidade, cedendo espaço e proporcionando visibilidade aos dois lados da guerra, com representatividade no Brasil. A inquietação discordante se revela, portanto, na intencionalidade travestida de interesse na manutenção ou construção de uma reputação, cuja força configura imageticamente uma concordância narrativa que se consolida pelas imagens veiculadas. A tradição do jornalismo moderno construído no século XIX é acionado, para dar equilíbrio à narrativa. 
Imagem 3 - A Cigarra, agosto de 1914

A Guerra Eurapéa

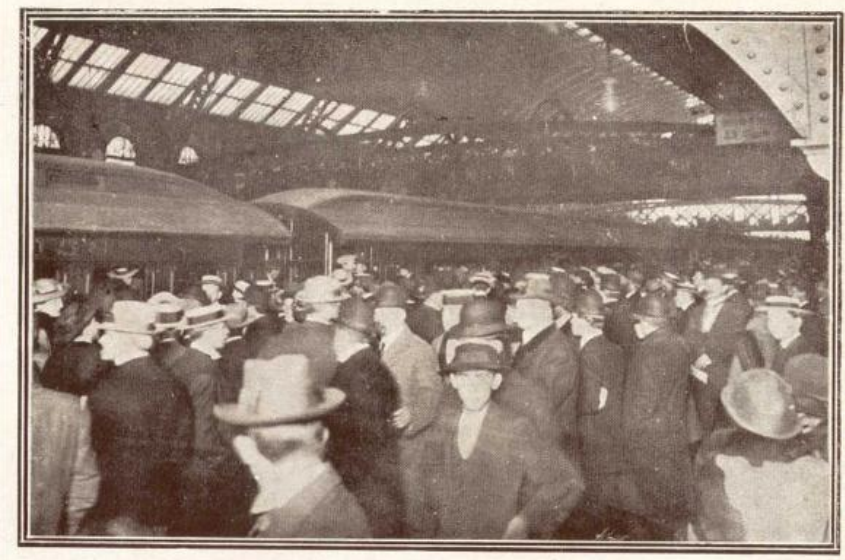

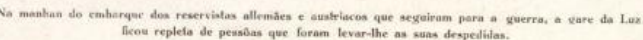

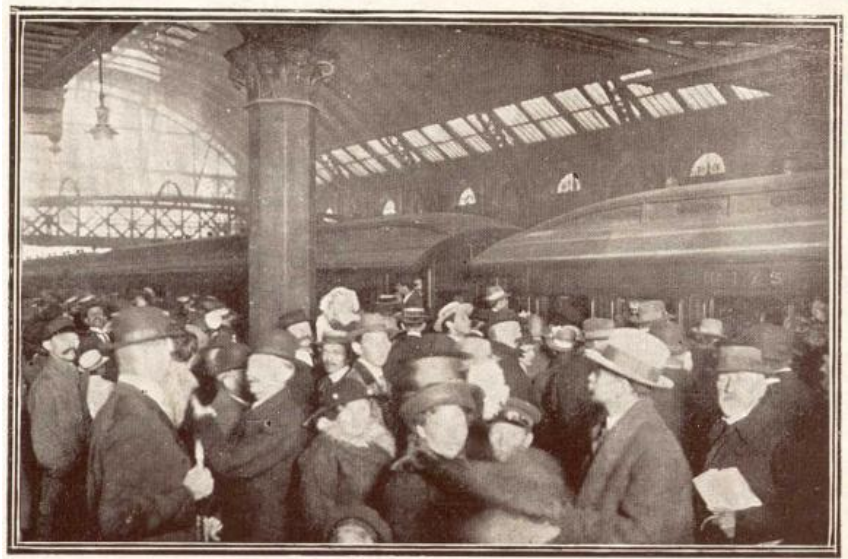

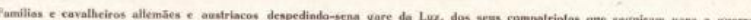

Fonte: Memória da Imprensa- Arquivo do Estado de São Paulo.

Todavia, a maior parte da cobertura (três páginas) foi dedicada aos oficiais franceses que estiveram em missão no Brasil, louvando-os e, portanto, retratando não apenas a importância que o governo e os paulistanos davam para a missão francesa. Essa postura já refletia o inicial momento de mobilização nacionalista que se iniciava no país, em que uma das primeiras questões aventadas era o maior e melhor aparelhamento e preparação das forças armadas. A França, nesse contexto, já era aliada do Brasil antes do início da guerra e as imagens tratavam de narrar essa condição. As narrativas visuais tratam de dar lugar para as tradicionalidades, em um visão ricoeuriana, enquanto correia de transmissão que visa interligar o presente à experiência, desse modo reforçando um relacionamento que remontava um acordo passado. Já na edição de setembro de 1914, a publicação tem início com uma imagem sobre os prisioneiros franceses em acampamento alemão (Imagem 4). Trata-se de uma gravura que procurava representar cenas da guerra; por sinal, um recurso muito usado 
por toda a imprensa da época, sobretudo o jornalismo francês, em periódicos como o Le Petit Journal (RÊGO; LEAL, 2015).

Imagem 4 - A Cigarra, setembro de 1914

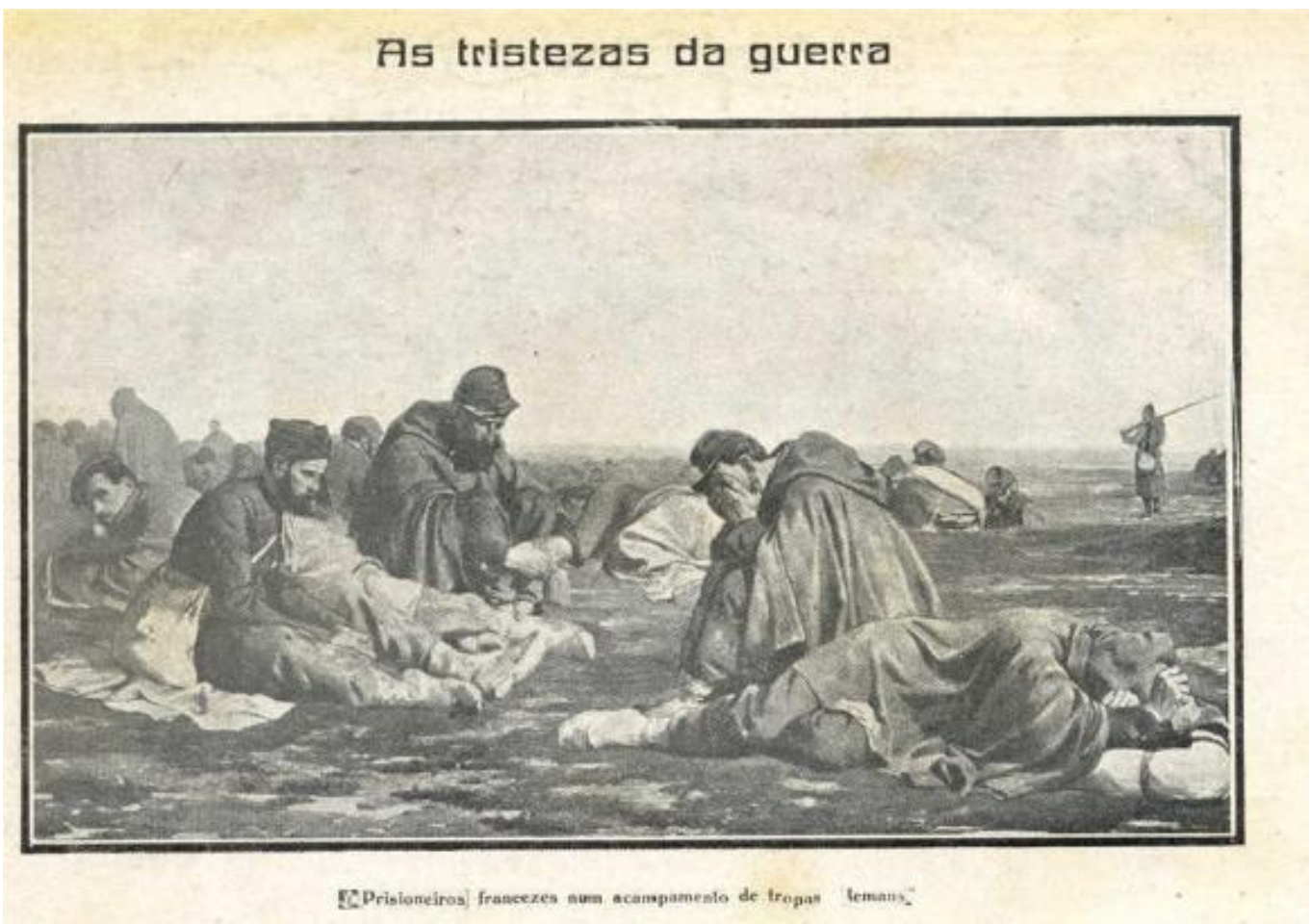

Fonte: Memória da Imprensa- Arquivo do Estado de São Paulo.

A imagem, em cuja legenda se lê sobre os prisioneiros franceses em acampamentos alemães, procura configurar um determinado contexto em busca da adesão e sensibilização do público leitor para o modo desumano como os alemães tratavam seus adversários. A desconstrução dos alemães e seus aliados passa a se fazer presente no periódico a partir dessa edição com maior ênfase e reflete o direcionamento tomado pela maioria dos jornais e revistas nacionais (RÊGO; LEAL, 2015).

Nesse mesmo exemplar é possível ainda localizar fotografias “jogadas" aleatoriamente ao longo da revista, como a Imagem 5, que se encontra no meio de um conto. 
Imagem 5 - A Cigarra, setembro de 1914

\section{Episadias da guerra}

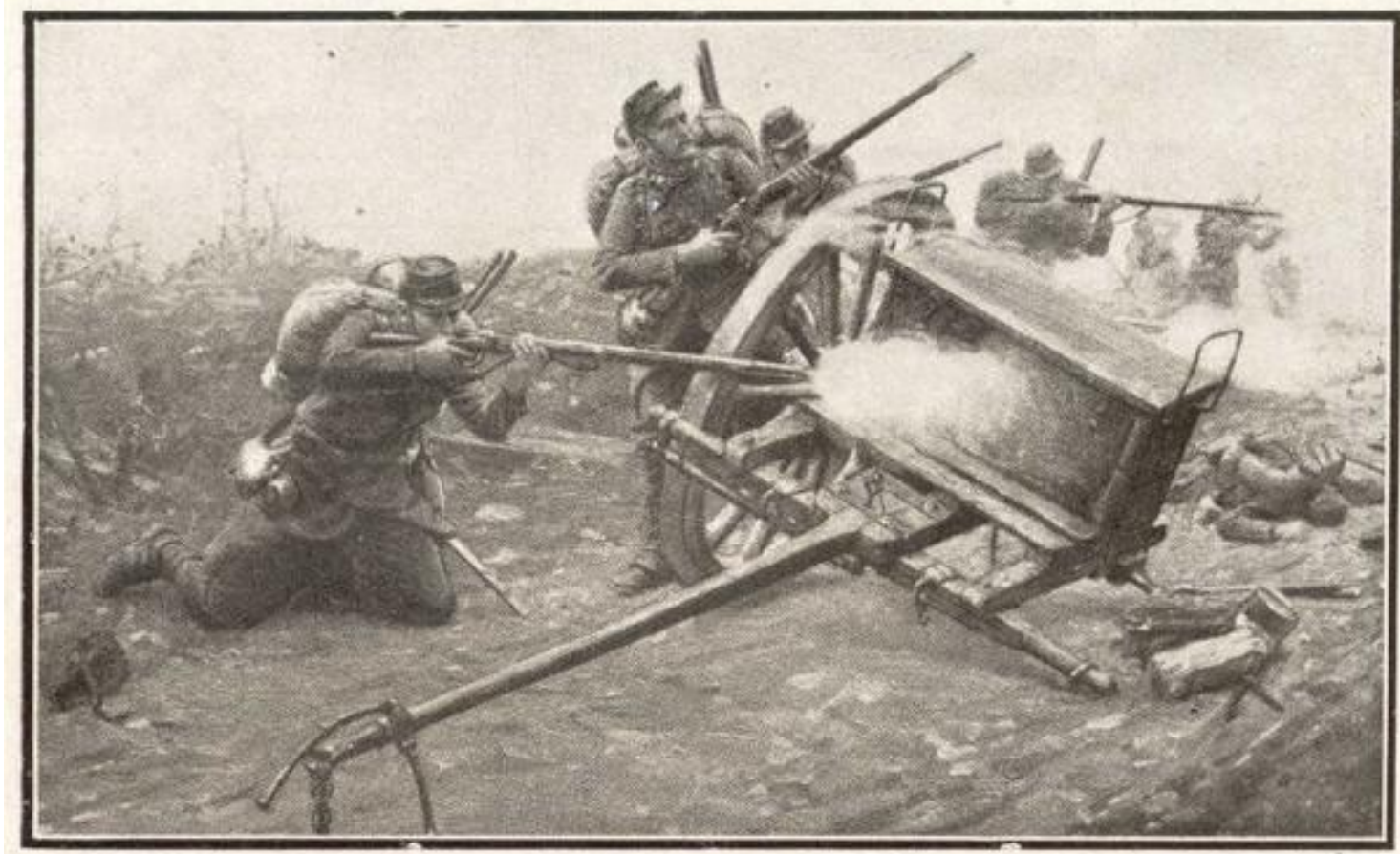

Soldados de infanteria franceza, num supremo_esforço, entrincheiram-se em una carroga para fozer fogo contra is Iropas allemans.

Fonte: Memória da Imprensa- Arquivo do Estado de São Paulo.

Novamente a imagem se refere às fronteiras da guerra em que franceses e alemães estão em disputa. A ação narrada traz uma visão com foco similar ao da imagem anterior, ou seja, a partir do lugar dos franceses e de seu supremo esforço para conter as forças alemãs. A configuração do real nas duas últimas imagens parte de um lugar social que privilegia a suposta lealdade brasileira aos franceses, também referendada em outros periódicos (RÊGO; LEAL, 2015), que incluem ainda os ingleses, refletindo nossos acordos comerciais e nossa influência cultural. A França, por sinal, é mais uma vez homenageada na revista na edição em pauta, no artigo "A morte de um ídolo" (sobre a Revolução Francesa). Contudo, nessa edição, setembro de 1914, a revista ainda procurava disfarçar sua posição e trazer informações sobre os alemães, buscando manter a imparcialidade. 
Imagem 6 - A Cigarra, setembro de 1914

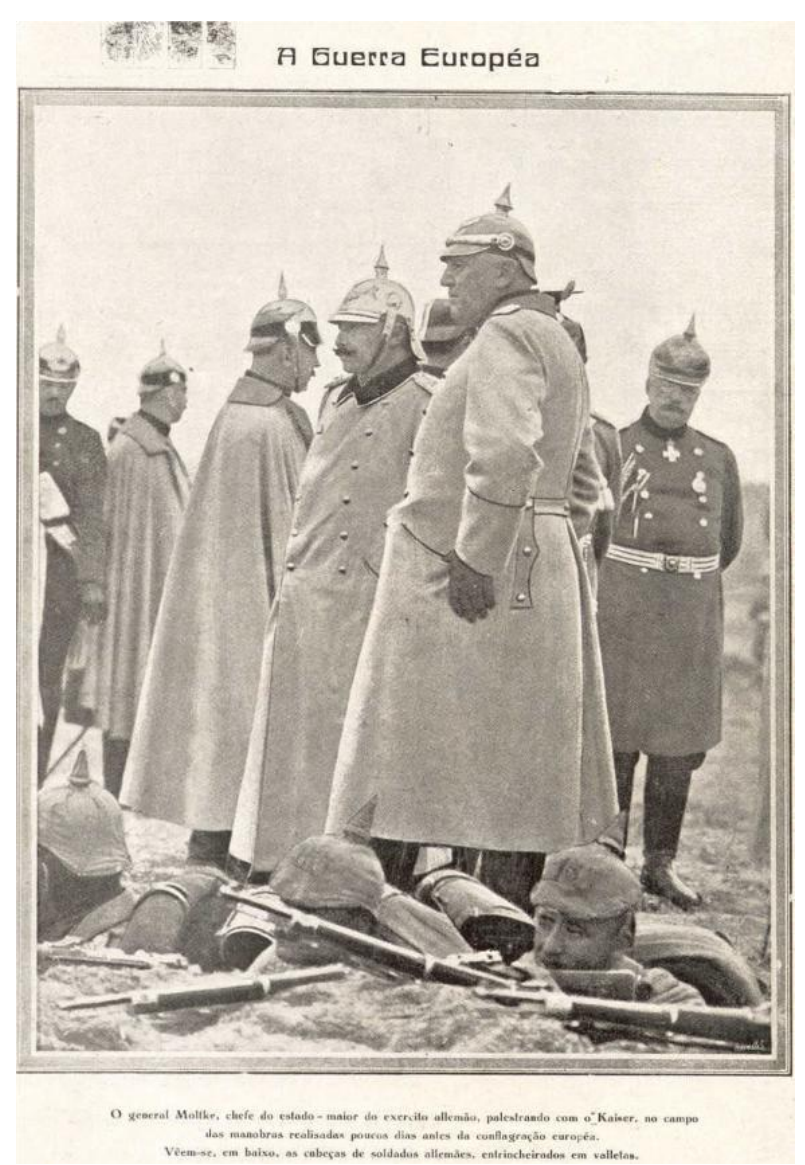

Fonte: Memória da Imprensa- Arquivo do Estado de São Paulo.

A ideia era apresentar uma certa isenção na cobertura, reforçando os valores que passaram a compor a reputação da instituição jornalística no final do século XIX. A exemplo da revista publicada em agosto daquele ano, em setembro, os alemães também são representados, embora com espaço menor. A imagem acima pode ser analisada na contextualidade da revista em seu universo de leitores, a partir de um possível contrato de leitura (VERÓN, 1980) do qual também faziam parte alemães e austríacos, tendo em vista a comunidade que vivia no Sudeste e no Sul do país.

Por outro lado, como já mencionado anteriormente, a desejada imparcialidade tenta se manter nesse momento inicial da Primeira Guerra, em que o Brasil declarava sua neutralidade no conflito, mas também em que iniciaria a exportar matéria prima, alimentos e, posteriormente, inclusive os primeiros artigos industrializados brasileiros para os países aliados da Tríplice Entente no continente europeu (REGO; LEAL, 2015), colocando-se contra as determinações alemães e travando uma verdadeira guerra paralela e não declarada com a nação germânica. 
Posteriormente, essas imagens se tornariam escassas nos periódicos brasileiros situados como aliadófilos, embora existissem também vários jornais germanófilos. O desaparecimento das imagens positivas dos alemães das páginas dos nossos periódicos se dá, principalmente, após o aprisionamento de vários navios alemães em águas brasileiras que viriam a ser incorporados a nossa esquadra e após o afundamento de parte da frota brasileira pelos alemães.

Em outubro de 1914 imagens da guerra da França invadem a capa da revista $A$ Cigarra, com a pergunta em língua francesa: Quem rirá por último?

\section{Imagem 7 - A Cigarra, outubro de 1914}

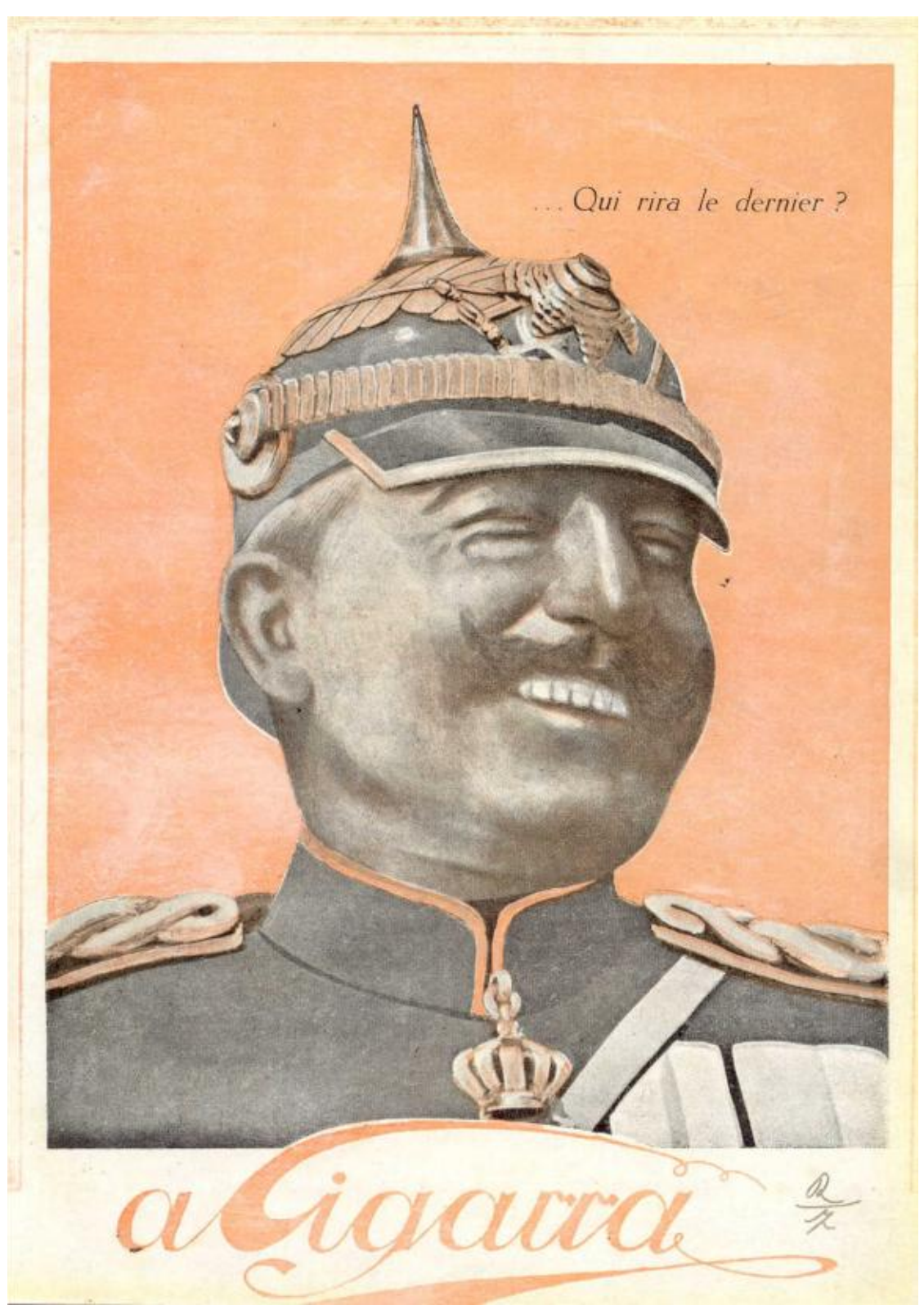

Fonte: Memória da Imprensa- Arquivo do Estado de São Paulo. 
A capa passa a ser contextualizada a partir da matéria sobre a guerra localizada nessa edição da revista A Cigarra, que fala sobre o cerco de Paris. Na verdade, uma narrativa em que o jornalista traz suas impressões sobre a cidade logo após o cerco ocorrido e sobre um possível encontro e diálogo ocorrido entre o narrador e um coronel francês. A ideia, tanto da imagem inicial como da narrativa textual sobre o cerco, era construir e/ou manter a imagem da França como uma nação que não sucumbe facilmente e que é capaz de se erguer mesmo nas maiores dificuldades (Imagem 8).

A visualidade da guerra volta a ser enfocada em meio a contos, crônicas e artigos do periódico.

Imagem 8 - A Cigarra, outubro de 1914

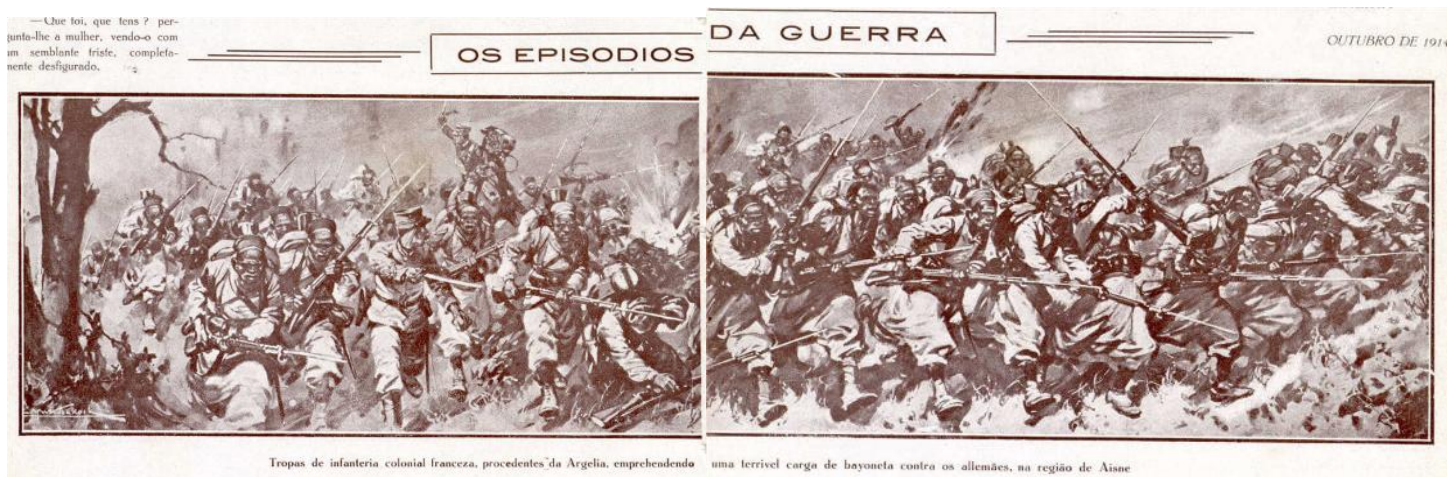

Fonte: Memória da Imprensa- Arquivo do Estado de São Paulo.

Novamente os personagens em destaque são os franceses que ferozmente e com muita coragem enfrentam os alemães. A configuração da narrativa visual reflete com recorrência o lugar em que o periódico se situa no conflito. Os representados em força e coragem são os franceses, logo, os aliados da Tríplice Entente. Na imagem não é possível identificar os alemães que estão sendo combatidos, mas tão somente a grande força do exército francês.

A próxima imagem da revista retrata a violenta luta travada entre os países e exalta o exército belga (Imagem 9). Destaca-se o processo de configuração do contexto conflituoso novamente pela ótica dos aliados da Tríplice Entente. Vale ressaltar que, nesse momento, no Brasil se realizavam as primeiras negociações e as primeiras conferências sobre a ideologia nacionalista no país e se buscava fortalecer, como dito anteriormente, as nossas forças, objetivando a entrada na guerra. Como afirmam Rêgo e Leal (2015), o Brasil somente entraria na guerra em 1917, mas a imprensa já estava em guerra desde 1914. 


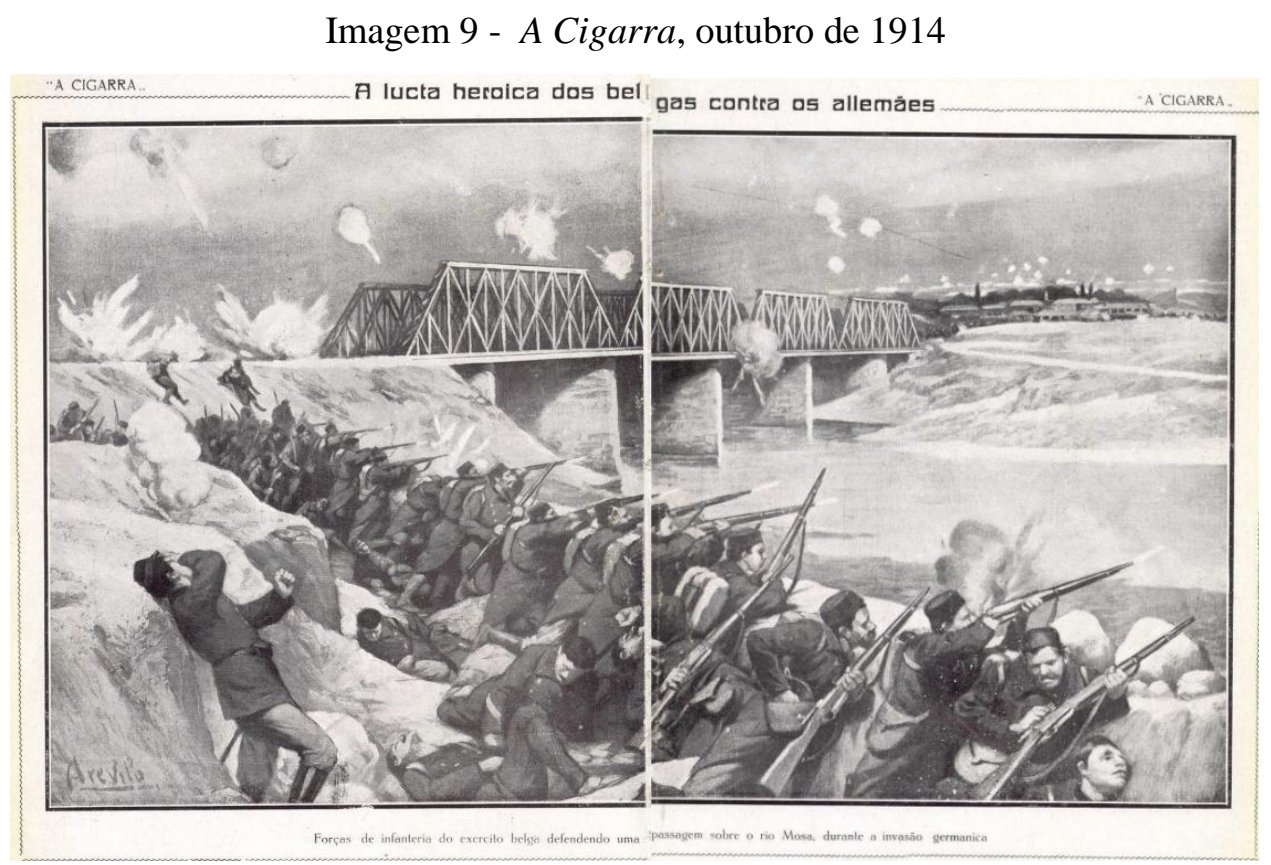

Fonte: Memória da Imprensa- Arquivo do Estado de São Paulo.

Em outubro de 1914 é possível visualizar ainda a luta inicial dos $\operatorname{russos}^{14}$ ao lado da Inglaterra e da França, contra os alemães. Na Imagem 10 a revista representa o momento em que o exército russo defende o seu território das forças alemãs invasoras.

Outra vez a visão imagética da guerra na revista em análise reflete a posição vigente no Brasil de apoio aos aliados da Entente. Os alemães não aparecem na gravura. Somente a força dos russos.

Percebe-se, portanto, que o periódico, embora situe o conflito e tome partido de um lado, também abria seu espaço para os que trabalhavam em prol de uma possível paz. Contudo, a partir de outubro de 1914, os alemães não mais serão representados de forma positiva, mas tão somente referenciados em combate contra os ingleses, franceses e demais aliados da Entente. O mundo bélico passa, no periódico, a ser configurado a partir de um olhar que sintetizava os anseios de um dos lados envolvidos na guerra. As ações narradas praticamente eliminam os atores do lado opositor, que são mencionados a cada narrativa imagética de modo negativo e sem visibilidade física.

Nessa edição, a revista apresenta ainda imagens em que os alemães são massacrados pelos ingleses e seus aliados, reforçando o argumento com que trabalham autores como Hastings (2014), Albert e Terrou (1990), Claro (2011) e Rêgo e Leal (2015), de que as

\footnotetext{
${ }^{14}$ Vale lembrar que com a deflagração da Revolução Russa em 1917, os russos abandonam a guerra (HASTINGS,2014).
} 
imagens e as demais narrativas buscavam adesões entre os componentes de cada sociedade envolvida no conflito e também nas sociedades periféricas.

Na edição de novembro de 1914, textos analíticos, narrativos e, ainda, ficcionais, tratam de desconstruir a nação alemã e seu povo, enquanto outros procuram criticar a guerra. Contudo, diversas fotografias e gravuras procuram situar o leitor diante do conflito em terras europeias, mantendo a linha já referenciada anteriormente (Imagem 10).

Imagem 10 - A Cigarra, novembro de 1914

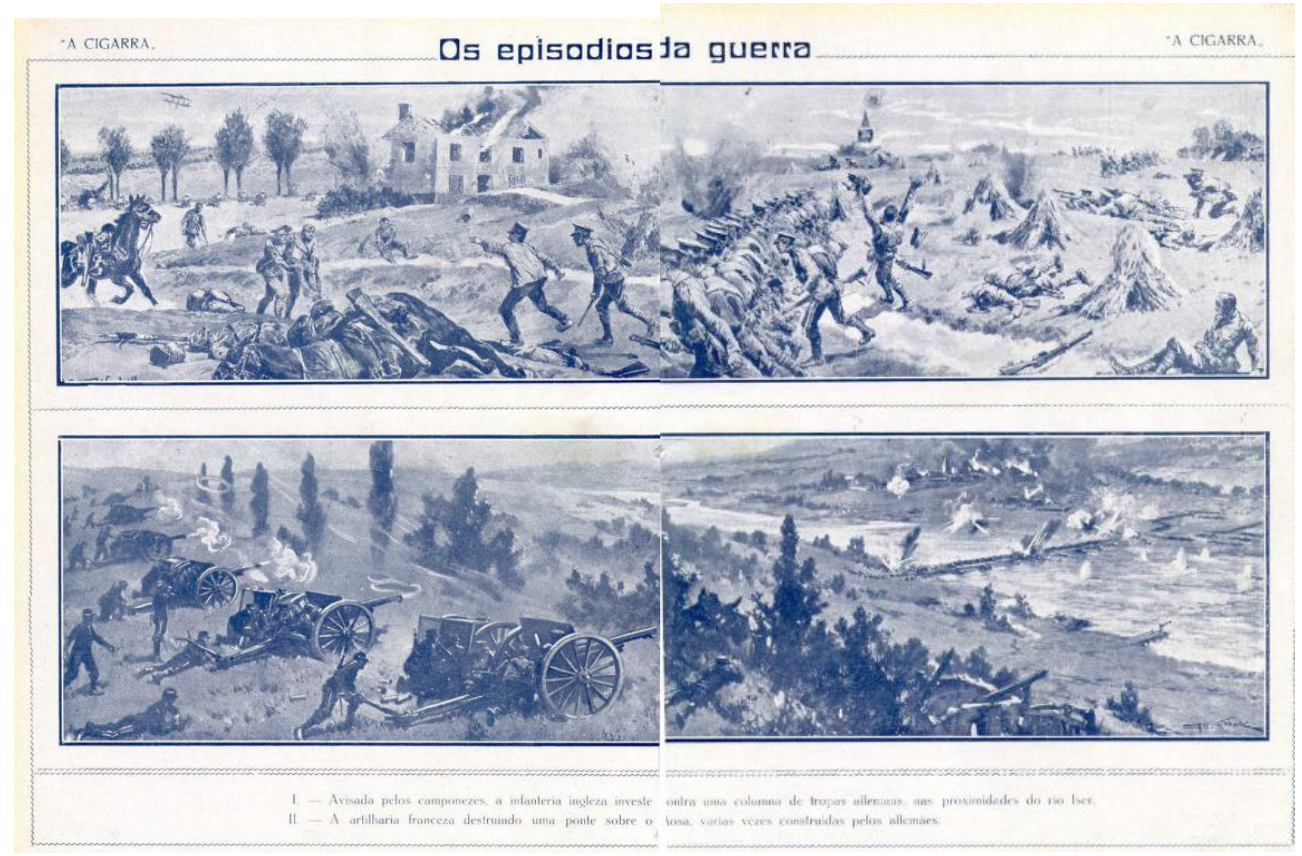

Fonte: Memória da Imprensa- Arquivo do Estado de São Paulo.

Nas cenas retratadas na Imagem 10, ingleses e franceses combatem os alemães em momentos distintos. Na cena superior, os camponeses avisam os ingleses sobre alemães nas proximidades do Rio Iser, na Polônia. Na gravura inferior, a artilharia francesa destrói uma ponte, várias vezes reconstruída pelos alemães. A configuração das ações narradas nas imagens aqui em análise se dá, mais uma vez, a partir do lugar dos aliados da Entente.

Os grandes males provocados pela guerra também ganham visualidade nas páginas de A Cigarra. Na narrativa visual na Imagem 11, os ingleses são socorridos em uma igreja transformada em hospital.

Esse posicionamento é idêntico ao adotado por imagens anteriores nas narrativas que revelam que a guerra, e, sobretudo, os alemães provocavam grande sofrimento aos aliados. A análise evidencia que quando se trata de paisagens sangrentas da guerra, as narrativas visuais 
são apresentadas por gravuras e não por fotografias. Nelas, a intencionalidade se reflete diretamente na imagem, de modo que a configuração da ação narrada seja compreendida e interpretada dentro de um lastro emocional previsto para se revelar no momento da refiguração da ação pelo leitor de A Cigarra, em seu tempo.

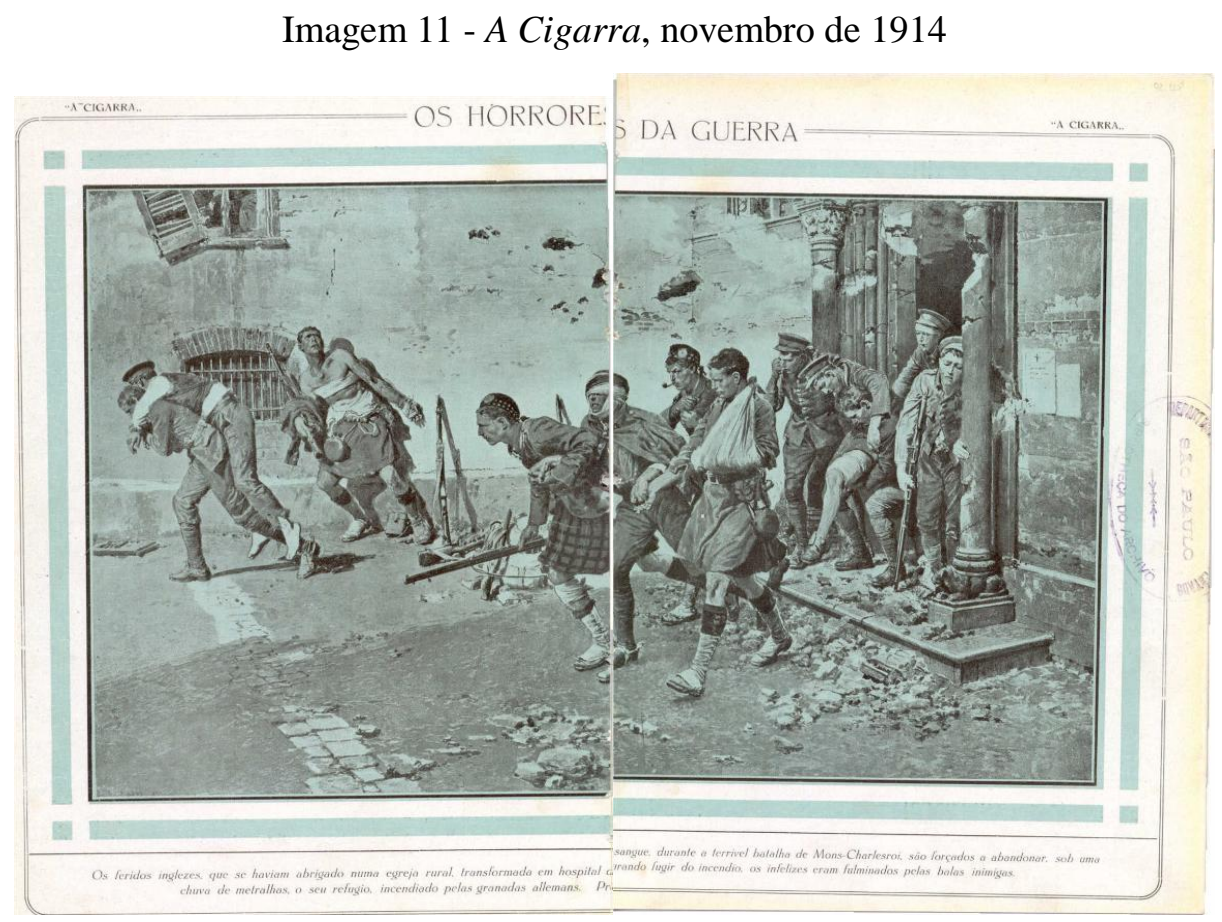

Fonte: Memória da Imprensa- Arquivo do Estado de São Paulo.

Logo em seguida, A Cigarra apresenta, em duas páginas com grandes imagens, a força pública de São Paulo, reforçando o posicionamento discursivo da maioria da imprensa sudestina brasileira, que era favorável a entrada do Brasil no conflito (RÊGO; LEAL, 2015). $\mathrm{Na}$ narrativa imagética de número 12 localizamos a intencionalidade na apresentação das forças militares brasileiras representadas pelos paulistas, lugar em que a revista se situava. 
Imagem 12- A Cigarra- novembro de 1914

Farça Publica de 5. Paula

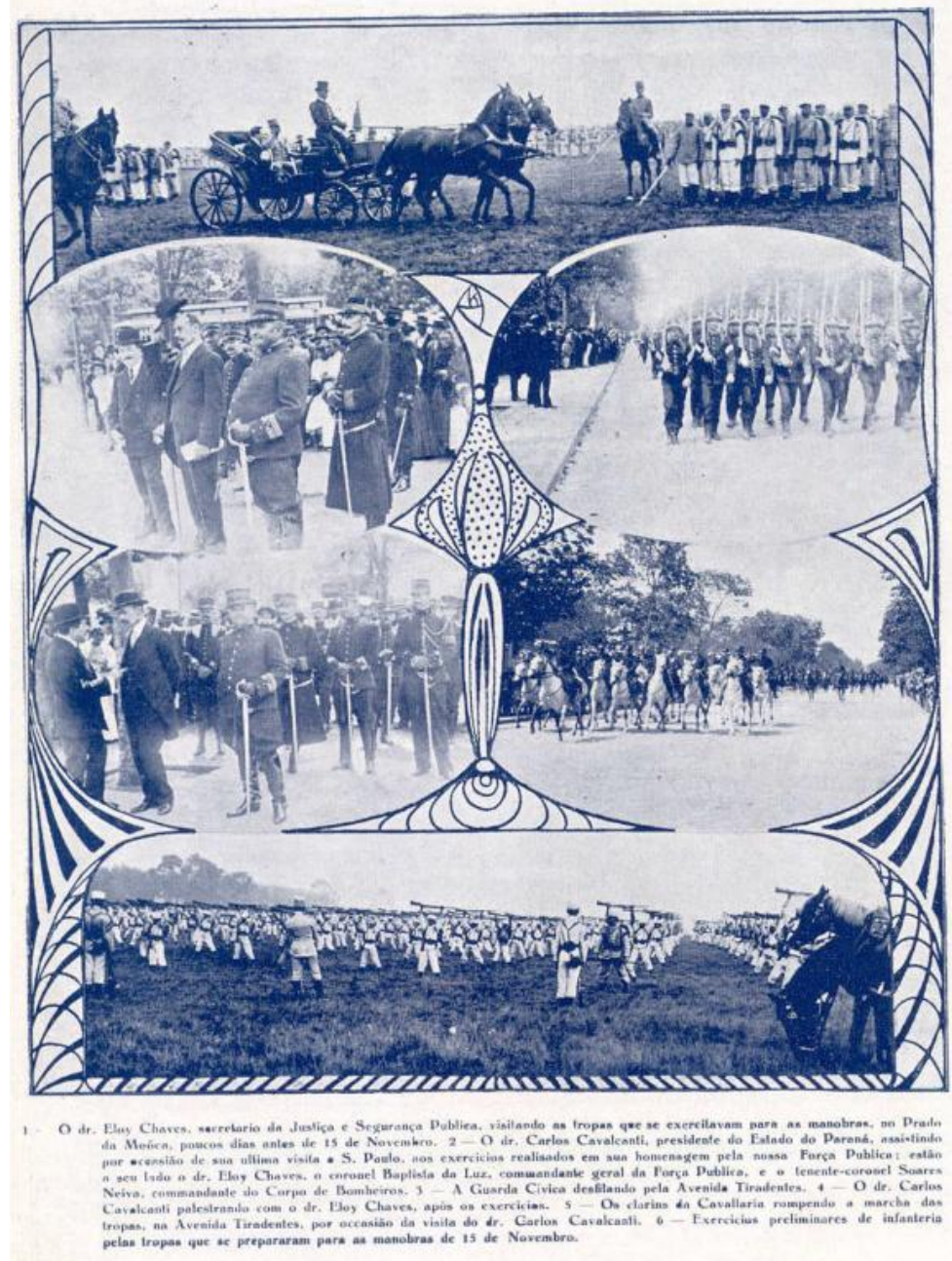

Fonte: Memória da Imprensa- Arquivo do Estado de São Paulo.

A Cigarra, no contexto da imprensa brasileira, também procurou configurar narrativas favoráveis à entrada do país no conflito. Foi o nacionalismo crescente em várias partes do globo que guiou, então, o debate público que alcançou os periódicos, configurando narrativas ancoradas em ideologias, desejos e intencionalidades que situavam as nações em lados opostos do conflito bélico. 


\section{Considerações finais}

Em 1914 o Brasil se declarou neutro no conflito que ora se iniciava, mas a imprensa e a sociedade já haviam tomado partido. Muitos eram favoráveis à entrada do Brasil já no primeiro ano da guerra. A maioria dos políticos, dos intelectuais e até mesmo dos jornalistas e de seus veículos de comunicação se colocou como apoiadores da Inglaterra, França e Rússia e demais aliados. Por outro lado, poucos eram apoiadores dos alemães e, ainda, pouquíssimos eram contrários ao conflito e à participação do Brasil.

A Cigarra, como periódico do sudeste brasileiro, reflete as condições contextuais em que se situava, atuando de modo similar à maioria dos veículos de comunicação de seu tempo e espaço. Reflete ainda, não somente possíveis posições político-ideológicas dos proprietários e redatores, mas também os anseios de seu público de interesse, revelando um possível contrato de leitura com a sociedade paulistana daquele início de século.

Em A Cigarra, os discursos localizados nas narrativas imagéticas oscilavam em torno da sensibilização por meio da apresentação das crueldades, sobretudo, dos alemães. Nesse caso, eram usadas as pinturas/gravuras, muito mais do que fotografias. Enquanto que, em outro prisma, os discursos privilegiavam a potência das forças armadas dos participantes da Tríplice Entente, sobretudo dos franceses, e adotavam quase um total silenciamento das forças alemães e de seus aliados, particularmente nas duas últimas edições analisadas.

É possível ainda perceber a tentativa de manutenção de uma certa imparcialidade em relação às nações envolvidas no conflito em determinados momentos, visto que, no Brasil, já existiam comunidades de cidadãos de países envolvidos nos dois lados da guerra. Todavia, a revista, na maioria das narrativas visuais, a partir de outubro de 1914, utilizava-se de construções negativas dos alemães e de seus aliados.

Outro recurso recorrente foi a representação dos exércitos dos aliados da Entente combatendo com muita coragem e força e os exércitos inimigos, no caso, os alemães e aliados, por sua vez, desaparecem das cenas visuais do ponto de vista de uma representação imagética, passando a ser apenas mencionados nas legendas.

Por fim, é possível ainda destacar que A Cigarra se situa potencialmente em seu tempo e suas narrativas visuais se utilizam de uma estética imagética da cena contemporânea compartilhada e comum a veículos de vários países no mesmo período. 


\section{Referências}

AGAMBEN, Giorgio. A potência do pensamento. Belo Horizonte: Autêntica, 2015.

ALBERT, Pierre; TERROU, Ferdinand. História da imprensa. São Paulo: Martins Fontes, 1990.

ARENDT, Hannah. A vida do espírito. Rio de Janeiro: Civilização Brasileira, 2016.

BRAGLIA, Nádia Christina. Paulicéia de ontem: as revistas ilustradas e o viver urbano nas primeiras décadas do século XX. 2011. Dissertação (Mestrado em História Social) Pontifícia Universidade Católica de São Paulo, São Paulo, 2011.

GARAMBONE, Sidney. A primeira guerra mundial e a imprensa brasileira. Rio de Janeiro: Mauad, 2003.

GILBERT, Martin.A primeira guerra mundial: os 1.590 dias que transformaram o mundo. São Paulo: Ed. Casa da Palavra, 2017.

GIORGIS, José Carlos Teixeira. A Grande Guerra na imprensa de Bagé. In: FLORES, Hilda Agnes Hübner; NEUBERGER, Lotário (org.). $1^{\text {a }}$ Guerra Mundial: reflexos no Brasil. Porto Alegre: CIPEL, EDIPLAT, 2014. p. 65-92.

HASTINGS, Max. Catástrofe - 1914: a Europa vai à Guerra. Rio de Janeiro: Intrínseca, 2014.

HEIDEGGER, Martin. Ser e Tempo. Petrópolis: Vozes, 2006.

MATOS, Hivana Mara Zaina de. A Revista A Cigarra no espaço urbano 1914-1934. In: ENCONTRO REGIONAL DE HISTÓRIA, 19., 2008, São Paulo. Anais [...]. São Paulo: ANPUH/SP-USP, $2008 . \quad$ Disponível em: http://legacy.anpuh.org/sp/downloads/CD\%20XIX/PDF/Autores\%20e\%20Artigos/Hivana\%2 0Mara\%20Zaina\%20de\%20Matos.pdf. Acesso em: 10 abr. 2017.

MENESES, Ulpiano T. Bezerra de. Preservação de acervos contemporâneos: problemas conceituais. São Paulo, 7 jun. 2006, MAC-USP. Disponível em: http://www.macvirtual.usp.br/mac/arquivo/noticia/Ulpiano/Ulpiano.asp. Acesso em: 24 abr. 2016.

PIRES, Lívia Claro. A Liga Brasileira pelos Aliados e o Brasil na Primeira Guerra Mundial. In: SIMPÓSIO NACIONAL DE HISTÓRIA, 26., 2011, São Paulo. Anais [...]. São Paulo: ANPUH, 2011.Disponível em: https://anpuh.org.br/uploads/anais-simposios/pdf/201901/1548856588_3f5386b0f9b7a41a71fb62dc5af0aee7.pdf. Acesso em: 14 dez. 2014.

RÊGO, Ana Regina; LEAL, Ranielle. Guerra de papel: confrontos sobre um conflito, atuação dos jornalistas, intelectuais e literatos na imprensa brasileira durante a Primeira Guerra Mundial. In: SOUSA, Jorge Pedro. Balas de papel: a imprensa ilustrada e a Grande Guerra (1914-1918): estudos sobre as revisas de Portugal, Brasil e Espanha. 1. ed. Lisboa: ED. Media XXI, 2015. p. 55-78. 
RICOEUR, Paul. Tempo e narrativa. São Paulo: Martins Fontes, 2010. 3 v..

RICOEUR, Paul. A memória, a história, o esquecimento. Campinas-SP: Ed. UNICAMP, 2012.

SILVESTRE, Fernanda Munhão Martins. As crônicas de Bilac nas revistas ilustradas A Cigarra (1895) e A Bruxa (1896-1897). 2008. Dissertação (Mestrado em Letras) - Faculdade de Ciências e Letras de Assis, Universidade Estadual Paulista, Assis, 2008. Disponível em: https://repositorio.unesp.br/handle/11449/94102. Acesso em: 10 jan. 2015.

SODRÉ, Nelson Werneck. História da imprensa no Brasil. 4. ed. Rio de Janeiro: Mauad, 1999.

VERÓN. VERÓN, Eliseo. A produção de sentido. São Paulo: Cultrix, 1980.

Submetido em 26.08.2020

Aprovado em 04.10.2020 